\title{
Spis treści
}

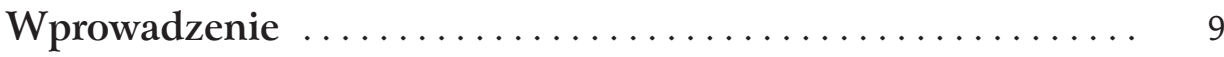

Bibliografia twórczości profesora Józefa Kozieleckiego …... 14

\section{CZĘŚĆ I}

Opowieść biograficzna Maryla Goszczyńska ............. 23

1. Wileńskie dzieciństwo $\mathrm{z}$ wojną $\mathrm{w}$ tle $\ldots \ldots \ldots \ldots \ldots \ldots$

2. Tucholska młodość $\ldots \ldots \ldots \ldots \ldots \ldots \ldots \ldots \ldots \ldots, \quad 32$

3. Z Pomorza do stolicy, na Uniwersytet $\ldots \ldots \ldots \ldots \ldots \ldots . . \ldots 38$

3.1. Od marzeń do ich realizacji $\ldots \ldots \ldots \ldots \ldots \ldots \ldots \ldots \ldots . \ldots . \ldots . \ldots$

3.2. Kłopoty $z$ samym sobą $\ldots \ldots \ldots \ldots \ldots \ldots \ldots \ldots \ldots \ldots, \quad 45$

3.3. Nauka, miłość i... małżeństwo ................. 52

4. Pierwsza podróż do świata wielkiej nauki ........... 56

5. Świat powoli staje otworem $\ldots \ldots \ldots \ldots \ldots \ldots \ldots \ldots . \ldots 2$

5.1. Kolejne podróże naukowe $\ldots \ldots \ldots \ldots \ldots \ldots \ldots \ldots \ldots, 62$

5.2. W krainie reniferów $\ldots \ldots \ldots \ldots \ldots \ldots \ldots \ldots \ldots \ldots \ldots \ldots$

5.3. Niemcy, 30 lat po wojnie $\ldots \ldots \ldots \ldots \ldots \ldots \ldots \ldots \ldots . \ldots 6$

5.4. W kraju samurajów i kwitnącej wiśni $\ldots \ldots \ldots \ldots \ldots \ldots \ldots$

6. Ponownie na kontynencie amerykańskim ........... 76

6.1. Ciałem już w Ameryce, a duchem i sercem w kraju $\ldots \ldots \ldots . \quad 76$

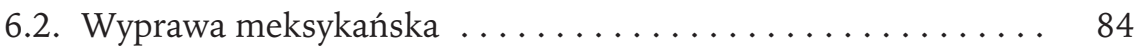

6.3. Z powrotem w Bloomington ................... 89

7. W trudnym czasie - trudne decyzje $\ldots \ldots \ldots \ldots \ldots \ldots . . \ldots 2$

8. Nie samą nauką człowiek żyje afirmacja wielowymiarowości $\ldots \ldots \ldots \ldots \ldots \ldots \ldots, 103$ 
9. Józef Kozielecki - Mentor? Mistrz? Wychowawca? . . . . . . 109

10. „Nigdy się nie poddaję”. Walka z przeciwnościami losu . 118

1 1. „Być twórczym i powięlkszać dorobek psychologii” ... . . 129

11.1. Najważniejsze dokonania Profesora Kozieleckiego . . . . . . . . 129

11.2. Przetwarzanie informacji $\mathrm{w}$ procesach myślenia

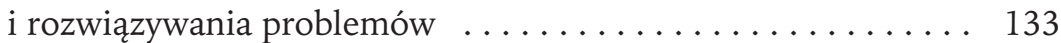

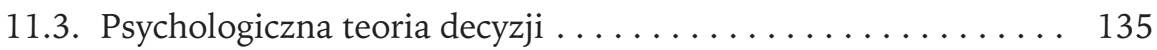

11.4. Koncepcja transgresyjna człowieka $\ldots \ldots \ldots \ldots \ldots \ldots .137$

\section{CZĘŚĆ II}

W oczach uczniów, współpracowników i przyjaciół . . . . . . . 141

Transgresje Profesora Kozieleckiego Czestaw S. Nosal . . . . . . . . . . 143

„Na Panu się nie poznałem” Zbigniew Zaleski . . . . . . . . . . . 152

Moje niemal półwiecze z Profesorem Kozieleckim Maryla Goszczyńska . . . 158

Ku Prawdzie i Transcendencji, czyli rzecz o doktorze honoris causa KUL

Józefie Kozieleckim Adam Biela . . . . . . . . . . . . . . . . . . . . 164

Pod wrażeniem Smutku spetnionych baśni Maria Jarymowicz . . . . . . . . 168

Garść wspomnień Jerzy Mroziak . . . . . . . . . . . . . . . . . . . 174

Mój niezwykły nauczyciel akademicki Elżbieta Strojna . . . . . . . . . . 179

O historii pewnej nagrody i coś więcej Barbara Bokus ............ 186

Jak zapamiętałam Profesora Barbara Mroziak . . . . . . . . . . . . . . 189

Kozielecki - Ziuk Krystyna Kofta . . . . . . . . . . . . . . . . . . . . . . 191

Pamięć pewnego incydentu Marta Gołębiewska (Gieorgica) . . . . . . . . . . 194

Józek Kozielecki, mój szkolny kolega Józef Zieliński . . . . . . . . . . . 197

ANEKS ............................ 199

Relacja z uroczystości nadania doktoratu honoris causa Profesorowi

Józefowi Kozieleckiemu Andrzej Sękowski . . . . . . . . . . . . . . 201

Laudacja Promotora profesora Andrzeja Sękowskiego . . . . . . . . . . . 204

Wykład profesora Józefa Kozieleckiego, doktora honoris causa . . . . . . 211

Literatura wykorzystana ................... 225

Noty o autorach ........................ 227

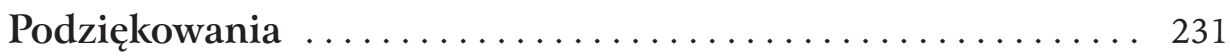

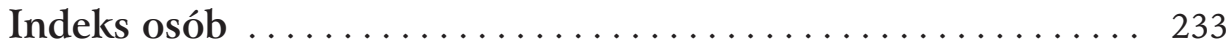

